\title{
An Investigation of Symptoms in Ethylene Oxide Sterilization Workers in Hospitals
}

\author{
Katsuya Yahata ${ }^{1}$, Kazuya Fujishiro ${ }^{2}$, Hajime HorI $^{3}$ and Toshiaki Higashi ${ }^{1}$ \\ ${ }^{1}$ The Institute of Industrial Ecological Sciences, ${ }^{2}$ Occupational Health Training Center, and \\ ${ }^{3}$ School of Health Sciences, The University of Occupational and Environmental Health, Japan
}

\begin{abstract}
An Investigation of Symptoms In Ethylene Oxide Sterilization Workers in Hospitals: Katsuya YAHATA, et al. The Institute of Industrial Ecological Sciences, The University of Occupational and Environmental Health, Japan - We investigated the frequency of particular symptoms reported during daily sterilization work with ethylene oxide (EO). By means of a self-administered questionnaire we received 287 replies from 66 institutions where sterilization work was performed, (148 used EO, and 139 used other substances). In these two groups, complaints such as stiff shoulders $(19.2 \%)$, low back pain $(13.9 \%)$, and skin burning $(13.2 \%)$ were frequently reported. When we compared the EO sterilization workers with other workers by means of Fisher's exact test, significant differences were observed among the cases of diarrhea, headache, dullness, sore throat and eye irritation. We also investigated some safety and health management factors that suggested correlations with the manifestation of these symptoms.

(J Occup Health 2001; 43: 180-184)
\end{abstract}

Key words: Ethylene oxide, Hospital, Symptom, Sterilization workers

Ethylene oxide (EO) is a gas widely used for sterilization in medical institutions. More than a million tons of EO is produced yearly and is used as a raw material for various chemical substances such as epoxy resin. Chemical industry statistics indicate that about 900 tons of $\mathrm{EO}$ is used annually for sterilization in medical institutions. Of the fifteen EO accidents reported in Japan between 1980 and 1999, six have involved sterilization work for medical purposes"

EO is highly reactive, and acute or chronic exposure

Received Nov 13, 2000; Accepted April 2, 2001

Correspondence to: $K$. Yahata, Department of Work Systems and Health, Institute of Industrial Ecological Sciences, University of Occupational and Environmenal Heaith, Japan, 1-1 Iseigaoka Yahatanishi-ku, Kitakyushu City; 807-8555, Japan to the gas $^{1,2)}$ is known to induce various toxic symptoms. All previous studies focused on the symptoms caused by acute or chronic exposure due to accidents, and there were very few previous studies that compared the symptoms reported by the workers who had been exposed to EO daily with those who had not. In our previous study, we investigated the actual conditions of industrial health management of the medical institutions that were performing EO sterilization ${ }^{4)}$.

In the present study, we investigated the relationship between the symptoms reported by EO workers and the management system in their facilities.

\section{Subject and Methods}

This study involved 99 hospitals located in a designated metropolitan area in Kitakyushu, Japan. Because of our previous study ${ }^{4)}$ which had investigated industrial health management in sterilization facilities, all of them were known to have sterilization facilities (including those with only heating sterilization facilities). We sent selfadministered questionnaires by mail to sterilization workers via the management sections of their hospitals. The questionnaire listed the objective and subjective symptoms that were frequently reported in case reports and other studies of acute and chronic exposure to EO ${ }^{5}$, as well as general symptoms such as low back pain.

The questionnaire consisted of two sections: the first section included basic questions such as the method of sterilization, the subject's sex, age, years of experience in the sterilization job, and daily hours spent on sterilization work. The second section included multiplechoice questions concerning 19 symptoms. If the subjects had any symptoms, they then selected one out of the following five categories: 1 . Felt only during sterilization work ('at work' in Table 3); 2 . Felt during the work or immediately after work and lingering for a while ('just after work' in Table 3); 3. Felt throughout the night after working ('after reaching home' in Table 3); 4 . Felt persistently and intensified during the work 
Table 1. Basic information obtained in this investigation

\begin{tabular}{lccc}
\hline & EO workers & non-EO workers & Total \\
Male $(\mathrm{n})$ & 21 & 10 & 31 \\
Female $(\mathrm{n})$ & 127 & 127 & 254 \\
not identified $(\mathrm{n})$ & 0 & 2 & 2 \\
Total $(\mathrm{n})$ & 148 & 139 & 287 \\
Age $(\mathrm{yr})$ & $37.5 \pm 11.9$ & $41.5 \pm 11.8$ & $39.5 \pm 12.0$ \\
Years of experience & $0.1-24.0$ & $0-32.0$ & \\
Duration of sterilizing work (h per day) & $0.2-10.0$ & $0.2-8.0$ & \\
\hline
\end{tabular}

('exacerbation by work' in Table 3); 5. Felt persistently regardless of the work ('unrelated to work' in Table 3).

We received responses from 67 institutions out of 99 (a response rate of $67.7 \%$ ), and a total of 287 workers responded. Among them, 148 were EO sterilization workers and 139 were non-EO sterilization workers. Table 1 shows the basic information data that appeared in the first section of the self-administered questionnaires. The ratio of women to men was approximately nine to one. The mean age was $39.5 \mathrm{yr}$, the length of experience was between 0 and $32 \mathrm{yr}$ (the mean was $6.5 \mathrm{yr}$ ), and the time spent on sterilization work was between 0.2 and 10 $\mathrm{h}$ (the mean was $3.1 \mathrm{~h}$ ).

The rate of male workers was $14.2 \%$ for $\mathrm{EO}$ workers and $7.2 \%$ for non-EO workers. The mean ages for $\mathrm{EO}$ workers and non-EO workers were 37.5 and 41.5, respectively. The length of experience was between 0.1 and $24 \mathrm{yr}$ (the mean was $5.5 \mathrm{yr}$ ) among EO workers and between 0 and $32 \mathrm{yr}$ (the mean was $7.7 \mathrm{yr}$ ) among nonEO workers. The length of time spent on sterilization work was between 0.2 and $10 \mathrm{~h}$ a day (the mean was 4.0 h) among EO workers and 0.2 and $8 \mathrm{~h}$ (the mean was 2.1 h) among non-EO workers. There were no significant differences between EO workers and non-EO workers in the length of experience and the length of time spent on sterilization work. It was found that both $\mathrm{EO}$ and nonEO workers were routinely engaged in heating sterilization and that much of their work content overlapped.

We also compared the results of this study with those of our previous study on safety and health management at medical institutions ${ }^{5}$ in order to find what management factors influenced the manifestation of subjective symptoms. Statistical analyses were done by odds ratio and Fisher's exact test with Statview ver. 5.0 (by Abacus Co.). In calculating the odds ratio, we checked the relationship between basic factors (age, sex, years of experience, duration of sterilizing work) and the 5 symptoms by using a logistic model for verifying independence.

\section{Results}

Table 2 shows the ratio of subjective symptoms among EO workers, non-EO workers and the total. Since the survey asked the subjects about the manifestation of work related symptoms, any answer, except for 'none', was interpreted to mean that they had symptoms. The reported symptoms in order of frequency were stiff shoulders (the number of subjects 55: $19.2 \%)$, low back pain $(40$ : $13.9 \%)$, skin burning (38: $13.2 \%)$, headache $(26: 9.1 \%)$, itching of the skin $(24: 8.4 \%)$, and irritation of the eyes (23: $8.0 \%)$.

Between the two groups there were significant differences in 6 of the following reported symptoms, diarrhea, headache, dullness, sore throat, eye irritation and low back pain. EO workers complained of these symptoms more frequently than non-EO workers with the exception of low back pain. Excluding low back pain we then investigated these 5 symptoms among EO workers in relation to the duration of their symptoms and their sterilization work.

Table 3 shows the relationship between the work and the time the subjects had any of the five symptoms. When the 3 work related items of 'at work' in Table 3 were added together we found that the number of workers who experienced eye irritation was $70 \%$, dullness was $69 \%$ and sore throat was $72 \%$. These 3 symptoms are thought to be typically related to acute EO exposure. On the other hand, the combined figures for headache were $26 \%$ and for diarrhea $0 \%$. These 2 symptoms are not common to EO exposure.

We compared the relationship between safety and health management factors from a previous study with these five subjective symptoms. Table 4 shows the results for the factors that showed significant differences (we also tested the relationship between the five symptoms and other factors such as age, sex, years of experience, duration of sterilizing work, clinics and hospitals, but no significant differences were found).

The management factors that were related to diarrhea depended on whether there was periodic maintenance and on whether the workers wore respiratory protective masks 
Table 2. Symptoms in sterilizing workers

\begin{tabular}{|c|c|c|c|c|c|c|}
\hline & \multirow[t]{2}{*}{ Symptoms } & \multicolumn{2}{|c|}{ EO workers (149) } & \multicolumn{2}{|c|}{ non-EO workers (137) } & \multirow{2}{*}{$\begin{array}{c}\text { Fisher's exact } \\
\text { test p value }\end{array}$} \\
\hline & & $\%$ & $\mathrm{n}$ & $\%$ & $\mathrm{n}$ & \\
\hline \multirow[t]{4}{*}{ Digestive } & Nausea & $4.1 \%$ & $(6)$ & $1.5 \%$ & (2) & 0.286 \\
\hline & Diarrhea & $4.1 \%$ & (6) & $0.0 \%$ & $(0)$ & $0.030^{*}$ \\
\hline & Constipation & $4.1 \%$ & (6) & $2.2 \%$ & (3) & $0 . \overline{504}$ \\
\hline & Epigastralgia & $4.7 \%$ & (7) & $3.6 \%$ & (5) & 0.771 \\
\hline \multirow[t]{5}{*}{ Central nervous system } & Headache & $15.5 \%$ & (23) & $2.2 \%$ & (3) & $0.0001 *$ \\
\hline & Vertigo & $2.7 \%$ & (4) & $0.7 \%$ & (1) & 0.372 \\
\hline & Sleeplessness & $2.0 \%$ & (3) & $0.7 \%$ & (1) & 0.623 \\
\hline & Dullness & $8.7 \%$ & (13) & $0.7 \%$ & (1) & $0.002 *$ \\
\hline & Numbness & $3.4 \%$ & $(5)$ & $2.2 \%$ & (3) & 0.724 \\
\hline \multirow[t]{2}{*}{ Musculoskeletal } & Shoulder stiffness & $18.9 \%$ & $(28)$ & $19.7 \%$ & $(27)$ & $>.999$ \\
\hline & Lumbago & $9.5 \%$ & (14) & $19.0 \%$ & (26) & 0.027 \\
\hline \multirow[t]{3}{*}{ Skin } & Eruption & $2.7 \%$ & (4) & $2.2 \%$ & (3) & $>.999$ \\
\hline & Itching & $8.1 \%$ & (12) & $8.6 \%$ & (12) & $>.999$ \\
\hline & Burn & $12.8 \%$ & (19) & $13.7 \%$ & (19) & 0.863 \\
\hline \multirow[t]{3}{*}{ Respiratory } & Sore throat & $7.4 \%$ & (11) & $0.0 \%$ & $(0)$ & $0.001 *$ \\
\hline & Cough & $3.4 \%$ & (5) & $2.2 \%$ & (3) & 0.724 \\
\hline & Difficulty in breathing & $0.0 \%$ & $(0)$ & $0.0 \%$ & $(0)$ & $>.999$ \\
\hline \multirow[t]{2}{*}{ Eye } & Eye irritation & $13.5 \%$ & $(20)$ & $2.2 \%$ & (3) & $0.001 *$ \\
\hline & Sebum & $0.7 \%$ & (1) & $1.4 \%$ & (2) & 0.612 \\
\hline
\end{tabular}

Table 3. Symptoms in EO workers and onset time

\begin{tabular}{lcccccccccc}
\hline & \multicolumn{2}{c}{$\begin{array}{c}\text { At work } \\
\%\end{array}$} & \multicolumn{2}{c}{$\begin{array}{c}\text { Just after } \\
\text { work }\end{array}$} & $\begin{array}{c}\text { After reaching } \\
\text { home }\end{array}$ & $\begin{array}{c}\text { Exacerbation } \\
\text { by work }\end{array}$ & $\begin{array}{r}\text { Unrelated } \\
\text { to work }\end{array}$ \\
\hline Eye irritation & $40 \%$ & $(8)$ & $25 \%$ & $(5)$ & $0 \%$ & $(0)$ & $5 \%$ & $(1)$ & $30 \%$ & $(6)$ \\
Dullness & $38 \%$ & $(5)$ & $23 \%$ & $(3)$ & $0 \%$ & $(0)$ & $8 \%$ & $(1)$ & $31 \%$ & $(4)$ \\
Sore throat & $27 \%$ & $(3)$ & $27 \%$ & $(3)$ & $0 \%$ & $(0)$ & $18 \%$ & $(2)$ & $27 \%$ & $(3)$ \\
Headache & $9 \%$ & $(2)$ & $17 \%$ & $(4)$ & $0 \%$ & $(0)$ & $0 \%$ & $(0)$ & $74 \%$ & $(17)$ \\
Diarrhea & $0 \%$ & $(0)$ & $0 \%$ & $(0)$ & $0 \%$ & $(0)$ & $0 \%$ & $(0)$ & $100 \%$ & $(6)$
\end{tabular}

or not. The odds ratio was 14.1 for periodic maintenance and 0.1 for supplied-air respirators.

The symptom of headache was related to whether or not there was a local exhaust fan for the gas cylinder. The odds ratio was 0.2 in the case of local exhaust ventilation of the sterilizers.

The symptom of dullness was related to whether the workers were aware the dangers of EO gas and whether there was a local gas exhaust for sterilizers. The odds ratio was 0.2 for local exhaust ventilation and 5.2 for hazard notification.

Fewer people complained of sore throat when they worked at institutions with periodic maintenance, an exhaust system for the facilities, and a local exhaust for sterilizers. The odds ratio was 8.9 for periodic maintenance, 28.8 for ventilation of the whole working area, and 6.9 for local exhaust ventilation.

The management factors that showed significant differences regarding the symptom of eye irritation were as follows: knowledge of the risks involved in EO gas, appointment of an industrial doctor, work gloves and protective clothes for the work.

\section{Discussion}

It has been reported that people exposed to the gas develop acute symptoms of gas poisoning such as headache, general malaise, restlessness, irritation of the skin, irritation of the conjunctiva, irritation of the throat, nausea, vomit, giddiness, dizziness and diarrhea ${ }^{2.5 \cdot 7)}$. Chronic exposure to the gas reportedly develops symptoms such as multiple peripheral neuropathy, headache and cataract ${ }^{2,8-15)}$. In medical sterilization most 
Table 4. Relationship between symptoms and management items

\begin{tabular}{|c|c|c|c|c|c|}
\hline Occupational Health management & $\begin{array}{c}\text { Diarrhea } \\
\text { Odds ratio } \\
\text { P-value }\end{array}$ & $\begin{array}{l}\text { Headache } \\
\text { Odds ratio } \\
\text { P-value }\end{array}$ & $\begin{array}{c}\text { Dullness } \\
\text { Odds ratio } \\
\text { P-value }\end{array}$ & $\begin{array}{c}\text { Sore Throat } \\
\text { Odds ratio } \\
\text { P-value }\end{array}$ & $\begin{array}{c}\text { Eye Irritation } \\
\text { Odds ratio } \\
\text { P-value }\end{array}$ \\
\hline $\begin{array}{l}\text { Ventilation of the whole } \\
\text { working area }\end{array}$ & $\begin{array}{l}14.9 \\
0.115\end{array}$ & $\begin{array}{l}2.4 \\
0.441\end{array}$ & $\begin{array}{l}5.1 \\
0.261\end{array}$ & $\begin{array}{l}28.8 \\
0.016\end{array}$ & $\begin{array}{l}12.5 \\
0.059\end{array}$ \\
\hline Local exhaust ventilation & $\begin{array}{l}1.0 \\
>.999\end{array}$ & $\begin{array}{l}0.5 \\
0.156\end{array}$ & $\begin{array}{l}0.2 \\
0.049\end{array}$ & $\begin{array}{l}6.9 \\
0.047\end{array}$ & $\begin{array}{l}0.3 \\
0.041\end{array}$ \\
\hline $\begin{array}{l}\text { Local exhaust ventilation of gas } \\
\text { at the opening of the sterilizer }\end{array}$ & $\begin{array}{l}2.6 \\
0.365\end{array}$ & $\begin{array}{l}0.2 \\
0.014\end{array}$ & $\begin{array}{l}0.1 \\
0.050\end{array}$ & $\begin{array}{l}1.1 \\
>.999\end{array}$ & $\begin{array}{l}0.5 \\
0.311\end{array}$ \\
\hline Removal of sterilized items & $\begin{array}{l}7.2 \\
0.189\end{array}$ & $\begin{array}{l}1.2 \\
>.999\end{array}$ & $\begin{array}{l}7.3 \\
0.073\end{array}$ & $\begin{array}{l}0.0 \\
>.999\end{array}$ & $\begin{array}{l}9.7 \\
0.025\end{array}$ \\
\hline Supplied-air respirators & $\begin{array}{l}0.1 \\
0.041\end{array}$ & $\begin{array}{l}- \\
-\end{array}$ & $\begin{array}{l}1.6 \\
0.599\end{array}$ & $\begin{array}{l}0.7 \\
0.537\end{array}$ & $\begin{array}{l}1.5 \\
>.999\end{array}$ \\
\hline Gloves & $\begin{array}{l}1.4 \\
>.999\end{array}$ & $\begin{array}{l}0.9 \\
>.999\end{array}$ & $\begin{array}{l}1.4 \\
0.764\end{array}$ & $\begin{array}{l}0.6 \\
0.521\end{array}$ & $\begin{array}{l}4.3 \\
0.012\end{array}$ \\
\hline $\begin{array}{l}\text { Protective clothing for } \\
\text { sterilization activities }\end{array}$ & - & $\begin{array}{l}1.6 \\
0.35\end{array}$ & $\begin{array}{l}3.9 \\
0.12\end{array}$ & $\begin{array}{l}1.7 \\
0.52\end{array}$ & $\begin{array}{l}4.5 \\
0.02\end{array}$ \\
\hline $\begin{array}{l}\text { Occupational health } \\
\text { physician appointment }\end{array}$ & $\begin{array}{l}1.2 \\
>.999\end{array}$ & $\begin{array}{l}0.8 \\
0.811\end{array}$ & $\begin{array}{l}2.0 \\
0.343\end{array}$ & $\begin{array}{l}0.8 \\
>.999\end{array}$ & $\begin{array}{l}3.0 \\
0.036\end{array}$ \\
\hline Recording of daily work content & $\begin{array}{l}7.2 \\
>.999\end{array}$ & $\begin{array}{l}1.0 \\
>.999\end{array}$ & $\begin{array}{l}0.5 \\
0.368\end{array}$ & $\begin{array}{l}1.2 \\
>.999\end{array}$ & $\begin{array}{l}0.3 \\
0.026\end{array}$ \\
\hline Hazard notification & $\begin{array}{l}1.3 \\
0.095\end{array}$ & $\begin{array}{l}0.9 \\
0.266\end{array}$ & $\begin{array}{l}5.2 \\
0.029\end{array}$ & $\begin{array}{l}0.9 \\
>.999\end{array}$ & $\begin{array}{l}3.9 \\
0.038\end{array}$ \\
\hline Periodical maintenance & $\begin{array}{l}14.1 \\
0.013\end{array}$ & $\begin{array}{l}0.9 \\
>.999\end{array}$ & $\begin{array}{l}1.6 \\
0.487\end{array}$ & $\begin{array}{l}8.9 \\
0.002\end{array}$ & $\begin{array}{l}1.5 \\
0.563\end{array}$ \\
\hline
\end{tabular}

workers are exposed to $\mathrm{EO}^{16-18}$, especially during the exhaust process. Previous studies have shown this exhaust time to be between 1 and $5 \mathrm{~min}$ and the exhaust level to be usually $0-5 \mathrm{ppm}^{18 j}$. Although this exposure is within the guidelines laid down by OSHA, there have been very few previous studies that have investigated the frequency of symptoms caused by daily exposure to the gas or compared EO workers with non-EO workers ${ }^{19}$.

In this study we found that EO workers significantly complained more of diarrhea, headache, dullness, sore throat and irritation of the eyes. Their symptoms were consistent with the known symptoms of EO poisoning. It is thought that headache is irrelevant to the work, but it may be related to chronic exposure ${ }^{2,5,6)}$. Although diarrhea had been considered as one of the symptoms due to acute exposure, our study found that it developed irrespective of the work.

We further investigated the relationship between management factors and the five symptoms. The factors that were related to more than one symptom included: knowledge of the risks, periodic maintenance, and installation of a local exhaust fan for sterilizers. Both knowledge of the risks and periodic maintenance were the factors that should be included in general management and not in work environment management.

Installation of local exhaust fans are counted among work environmental management factors, but subjects working at institutions without the device reported symptoms less frequently. This is probably because neither the frequency of EO sterilization work nor the nature of it was adequately addressed by the selfadministered questionnaire. In other words, it is highly likely for subjects to be exposed to high levels of EO for a short time in large-scale facilities even if the management of local exhaust was adequate. On the other hand, subjects working at smaller facilities were less likely to be exposed to high levels of EO even though the management of exhaust was inadequate because the amounts of EO used in such facilities were limited. Together with the results of this study, further itemization of the management factors and on-the-spot investigation are necessary in order to obtain more accurate information. 


\section{Conclusion}

Our study has confirmed that daily sterilization work with EO in hospitals can induce acute or chronic symptoms in EO sterilization workers. These symptoms were related to some safety and health management factors, but the subjects working in facilities with good management did not necessarily have fewer symptoms, due to various causes including accidental exposure.

This study was conducted as an entrusted research project funded by the Ministry of Labor from 1997 to 1998.

\section{References}

1) Yahata K, Fujishiro K, Hori H. The ethylene oxide sterilization accidental cases. Occupational Health Journal 1999; 22: 19-22 (in Japanese).

2) World Health Organization. Environmental health criteria 55 ethylene oxide. Geneva. World Health Organization, 1985.

3) Yahata K, Higashi T. Ethylene oxide. occupational health for health care workers. Netherlands: Elsevier Science, 1999: 125-127.

4) Yahata K, Higashi T, Yoshizumi K, Fujishiro K, Hori $\mathrm{H}$, Funatani F. An investigation on ethylene oxide sterilization management in medical institutions. San Ei Shi 2000; 42: 41-48.

5) Fujishiro K, Mori K, Inoue N. A survey of ethylene oxide sterilization in a hospital. J UOEH 1991; 13: $257-260$.

6) Fujishiro K, Inoue N, Mori K, Hashimoto T. Acute toxicity of ethylene oxide report of two cases from a hospital. JJTOM 1992; 40: 271-275.

7) Fujishiro K, Yahata K, Higashi $T$, Narisada $H$, Oda $S$, Okubo T. Acute ethylene oxide poisoning in japanese hospitals. The 4th ICOH International Conference on Occupational Health for Health Care Workers Keynote Addresses and Abstracts 1999: WP-37.

8) William J. Estrin, Stuart A. Cavalieri, Peter Wald, Charles E. Becker, Jeffrey R. Jones, James E. Cone. Evidence of neurologic dysfunction related long-term ethylene oxide exposure. Arch Neurol 1987; 44: 1283 1286.

9) Mori K, Ohnishi A, Fujishiro K, Inoue N. Effect of sexual difference on the toxicity of ethylene oxide. J UOEH 1990; 12: 61-66.

10) Ohnishi A, Inoue $N$, Yamamoto $T$, et al. Ethylene oxide induces central-peripheral distal axonal degeneration of the lumbar primary neurones in rats. Br $\mathbf{J}$ Ind Med $1985 ; 42: 373-379$.

11) Estrin WJ, Bowler RM, Lash A, Becker CE. Neurotoxicological evaluation of hospital sterilizer workers exposed to ethylene oxide. J Toxicol Clin Toxicol 1990; 28: 1-20.

12) Kuzuhara S, Kanazawa I, Nakanishi T, Egashira T. Ethylene oxide polyneuropathy. report of 2 cases with biopsy studies of nerve and muscle. Rinsho Shinkeigaku 1982; 22: 707-713.

13) Okuyama K, Abe E. Ethylene oxide polyneuropathy four cases report. JJTOM 1989; 37: 506-509.

14) Walter MJ, Thomas R. Swift, David S. Hull. Possible relationship of ethylene oxide exposure to cataract formation. Am J Ophthalmol 1982; 93: 727-732.

15) Deschamps D, Leport $M$, Laurent A-M, Cordier S, Festy B, Conso F. Toxicity of ethylene oxide on the lens and on leukocytes: an epidemiological study in hospital sterilization installations. Br J Ind Med 1990; 4: 308-313.

16) Virginia $M$. Weaver. Chemical hazards in health care workers. Occup Med 1997; 12: 655-667.

17) Annie Sobaszek, Jean Claude Hache, Paul Frimat, Vidah Akakpo, George Victoire, Daniel Furon. Working conditons and health effects of ethylene oxide exposure at hospital sterilization sites. J Occup Environ Med 1999; 41: 492-499.

18) Koda $S$, Kumagai $S$, Ohara H. Environmental monitoring and assessment of short-term exposures to hazardous chemicals of a sterilization process inhospital working environments. Acta Med Okayama 1999; 53: 217-223.

19) Roy EJ. Chronic toxicity of ethylene oxide. Arch Environ Health 1964; 6: 700-710. 